\title{
Responses to postruminal infusions of graded levels of casein in lactating goats
}

\author{
By S. S. E. RANAWANA* AND R. C. KELLAWAY \\ Dairy Husbandry Research Unit, Department of Animal Husbandry, \\ University of Sydney, Camden, New South Wales 2570, Australia \\ (Received I December r975-Accepted 8 March 1976)
}

I. A study was made in goats of the response in terms of milk production, nitrogen utilization, plasma amino acids and amino acid uptake by the mammary gland, to postruminal infusion of casein. Goats in early lactation, housed in metabolism cages, were fed on $2.5 \mathrm{~kg}$ basal ration/d (containing III g crude protein $(\mathrm{N} \times 6.25) / \mathrm{kg}$ ) and were given, by infusion into the abomasum, $0,15,30$ or $45 \mathrm{~g}$ casein/d.

2. Milk production increased from $2.4 \mathrm{I} \mathrm{kg} / \mathrm{d}$ on the basal ration to $2.52,2.80$ and $2.94 \mathrm{~kg} / \mathrm{d}$ in response to infusions of 15,30 and $45 \mathrm{~g}$ casein/d respectively. Milk composition was unaffected except for milk fat, which was slightly decreased during infusions of the higher levels of casein.

3. The goats were found to be in positive $\mathrm{N}$ balance on the basal ration. Milk $\mathrm{N}$ output increased with casein infusion; the increase was equivalent to a maximum of $49 \%$ of the infused $\mathrm{N}$.

4. The concentration of glucose in arterial blood plasma was decreased at the highest level of casein infusion, but that of plasma urea $\mathrm{N}$ was unaffected by treatments.

5. Casein infusions increased the concentrations of total indispensable amino acids and the ratio, indispensable: dispensable amino acids in arterial plasma. Arterial concentrations and mammary extractions of most indispensable amino acids were increased, but only a few increases were statistically significant $(P<0.05)$.

6. Comparison of individual indispensable amino acids absorbed from the intestine with output in milk indicated that methionine was probably the first limiting amino acid.

7. The results of the experiment were compared to those of similar experiments with cows that have been reported by other workers. The possible ways in which the infused casein may have caused the responses were discussed. However, no firm conclusions regarding the mechanism involved could be drawn from the results of the present study.

It is believed that the dietary protein allowance of a lactating ruminant is sufficient, when any further increase in the intake of digestible crude protein (DCP) fails to evoke a corresponding increase in milk production (Broster, 1972). In the ruminant, however, a varying proportion of apparently digested nitrogen is absorbed as a nonamino-N. The intake of DCP, therefore, bears little relationship to the actual quantities and proportions of amino acids presented for absorption (Satter \& Roffler, I975), and so it cannot be said with certainty that the amino acid supply from a particular dietary intake of DCP is adequate in relation to the requirements for milk production.

The direct effect of a nutrient on lactation can be assessed if it is supplied postruminally. Several recent reports (Hale, Jacobson \& Hemken, 1972; Clark, Spires \& Derrig, I973; Derrig, Clark \& Davis, 1974) have shown that postruminal infusion of casein stimulates milk production in cows. Responses have been recorded even when the dietary intake of DCP was adequate by accepted feeding standards (Clark et al

- Present address: Veterinary Research Institute, Peradeniya, Sri Lanka. 
1973; Vik-Mo, Emery \& Huber, I974a). It is not clear whether the infused casein either supplied amino acids that were deficient in the digesta passing from the rumen, or stimulated milk production in some other way. The present study was an attempt to identify the mechanisms involved in the response.

Goats in early lactation, fed on a low-crude-protein ration, were infused into the the abomasum with increasing quantities of casein and the resultant effects on the production of milk and its constituents, on $\mathrm{N}$ balance, and on arterial concentrations and mammary extractions of plasma-free amino acids, were measured. An attempt was also made to estimate the amino acids reaching the abomasum from the basal diet using chromium sesquioxide as a marker.

\section{EXPERIMENTAL}

\section{Design}

The experiment was conducted in a $4 \times 4$ Latin-Square design, with four animals and four treatments, and was carried out in four periods so that each animal was subjected to each treatment. After an initial $7 \mathrm{~d}$ on the basal ration, the animals were assigned at random to the four treatments, which consisted of infusing $0,15,30$ or $45 \mathrm{~g}$ casein/d into the abomasum. Each period lasted $\mathrm{I} 2 \mathrm{~d}$ and all measurements were carried out during the last $5 \mathrm{~d}$ of each period.

\section{Animals}

Four multiparous Saanen goats of about $50 \mathrm{~kg}$ live weight with similar milk yields, and free of obvious abnormalities of the mammary glands, were used. About $7 \mathrm{~d}$ after parturition, the goats were fitted with abomasal cannulas according to the procedure described for sheep by Driedger, Condon, Nimrick \& Hatfield (1970). At the same operation, the right carotid artery was dissected out and fixed subcutaneously. Postoperative care consisted of administration of daily injections of antibiotics $(25 \mathrm{mg}$ procaine penicillin and $25 \mathrm{mg}$ dihydrostreptomycin sulphate/ $\mathrm{kg}$ live weight) for $7 \mathrm{~d}$ and infusion of $100 \mathrm{~g}$ glucose/d into the abomasum for $3 \mathrm{~d}$. Recovery was uneventful and the experiment commenced 3-4 weeks after surgery.

The goats were housed in metabolism cages designed for separate collection of urine and faeces. By using an automatic feeding device the animals were offered a fresh portion of their daily allowance every $3 \mathrm{~h}$. Water and a salt lick $(\mathrm{g} / \mathrm{kg})$ : sodium chloride 590 , calcium oxide 180 , phosphoric acid 9.2 , iron 3.6 , sulphur 8.2 , copper 0.3 , cobalt 0.08 , magnesium oxide $\circ \cdot 16$ ) were made available ad lib. Before the start of the experiment, animals were treated with an anthelmintic (Thiabendazole; Merck, Sharp \& Dohme, Sydney) and injected with $300 \mathrm{mg}$ retinol equivalent and $4 \mathrm{mg}$ cholecalciferol equivalent. Hygienic precautions were adopted at milking times and the mammary glands were tested for any evidence of subclinical mastitis before and regularly during the experiment, by the California Mastitis Test. 
Table 1. Composition of basal ration fed to goats $(\mathrm{g} / \mathrm{kg})$

\begin{tabular}{lrlr}
\multicolumn{1}{c}{ Ingredient } & \multicolumn{2}{c}{ Analysis } \\
Milled barley & 620 & Crude protein & I I I \\
Lucerne hay & 200 & Acid-detergent fibre & 179 \\
Oat straw & 100 & Lignin & 52 \\
Bone meal & 10 & Dry matter & 869 \\
Molasses* & 70 & &
\end{tabular}

- Protojen; Australian Wheatgrowers Corporation: composition (g/kg) crude protein $(\mathrm{N} \times 6.25) 90$, crude fat $10-25$, crude fibre $28-40$, ash $86, \mathrm{~N}$-free extract 720 .

Table 2. Composition of solution infused into the abomasum

$$
\text { of lactating goats }(/ l)
$$

$\begin{array}{lr}\text { Sodium carbonate } & 3.31 \mathrm{~g} \\ \text { Casein* } & 50.00 \mathrm{~g} \\ \text { Dihydro streptomycin sulphate } & 62.5 \mathrm{mg} \\ \text { Procaine penicillin } & 62.5 \mathrm{mg} \\ \text { ('Total nitrogen } & 6.98 \mathrm{~g} \text { ) }\end{array}$

* Commercial acid-precipitated casein, mesh 30 ('Extra Grade'). The North Western Dairy Co. Ltd, Devonport, Tasmania.

\section{Feeding}

The ration shown in Table I was mixed, pelleted and $2.5 \mathrm{~kg}$ was fed to each goat daily. The animals were deliberately restricted to $2.5 \mathrm{~kg}$ (approximately $80 \%$ of the ad lib. intake) so that treatment effects would not be confounded by varying $\mathrm{N}$ intakes.

\section{Infusions}

The casein infusate (Table 2) was prepared as follows. Sodium carbonate was dissolved in water warmed to $40^{\circ}$ and the casein was added slowly while stirring. Stirring was continued for another $30 \mathrm{~min}$, after which the solution was made up to volume, filtered through glass wool and antibiotics added.

The casein solution was infused continuously using a peristaltic pump (LKBProducteur, Sweden). Different flow rates were obtained by employing two sizes of pump tubes and a range of gears. During the appropriate period o, 300, 600 or $900 \mathrm{ml}$ infusate was pumped daily in order to provide $0,15,30$ and $45 \mathrm{~g}$ casein/d respectively. The infusion tube (medical grade, $1 \cdot 50 \mathrm{~mm}$ i.d., $2 \cdot 70 \mathrm{~mm}$ o.d.) was suspended from a beam hung over the cage and passed into a rigid tube $20 \mathrm{~mm}$ i.d.) which was attached to a leather collar fitted to the goat. The infusion tube was brought out at the end of the rigid tube, passed over the animal's shoulder and into the abomasum using the cannula as a conduit. The rigid tube was secured with elastic to a mobile metal ring which in turn was attached to the beam overhead. This arrangement allowed the animal freedom of movement while denying any access to the infusion tube. 


\section{Milking}

Goats were milked by hand twice/d, by the same milker, throughout the experiment. Milk was weighed (to nearest $0 . \mathrm{I}$ ), recorded, sampled $(5 \%, \mathrm{w} / \mathrm{w})$ while stirring and all the samples from one animal in each period stored at $4^{\circ}$ after adding one drop of formalin ( $400 \mathrm{~g}$ formaldehyde/1)/20 $\mathrm{ml}$ milk. At the end of the period, samples of milk were homogenized and analysed for total solids (Davis, 1959), fat (Davis \& McDonald, I953), lactose (Cowie, Hartmann \& Turvey, I969), total crude protein $(\mathrm{N} \times 6 \cdot 38)$ and casein (Rowland, $\mathrm{r} 938)$.

\section{$N$ balance}

Urine and faeces were collected and measured daily from each animal during the experimental periods. To minimize loss of volatile $\mathrm{N}, 50 \mathrm{ml} 5 \mathrm{M}-\mathrm{HCl}$ was placed in the urine collector daily. Samples of urine $(5 \%, \mathrm{v} / \mathrm{v})$ were pooled for each period and stored at $-10^{\circ}$. Faeces were dried daily in a forced-draught oven at $65^{\circ}$ and sampled $(5 \%)$ at the end of the period. Samples of diet were taken regularly during the experiment. Milk, urine and milled samples of diet and faeces were analysed for $\mathrm{N}$ content using a Kjeldahl procedure adapted from McKenzie \& Wallace (1954).

\section{Blood samples}

A pair of blood samples was taken from each animal on the last day of each period. A vinyl catheter was inserted into one of the subcutaneous mammary veins and secured with a suture. The exteriorized carotid artery was pierced with a 20-gauge needle attached by a flexible coupling to a $50 \mathrm{ml}$ syringe. A $30 \mathrm{ml}$ blood sample was withdrawn simultaneously from each of the two vessels. The external pudic veins draining the mammary gland were clamped manually during the procedure (Linzell, 1960). Local analgesics were used throughout the procedure in order to avoid excitement. The goats were accustomed to being handled and normally remained calm. If, however, an animal became agitated, sampling was abandoned and repeated later.

Blood was mixed with solid ethylene diamine tetraacetic acid (EDTA) $(2 \mathrm{mg} / \mathrm{ml})$ and centrifuged, and a ro $\mathrm{ml}$ aliquot of plasma was deproteinized with $500 \mathrm{mg}$ sulphosalicylic acid (Petty \& Hansen, 1959) after adding $\mathbf{r} \cdot 25 \mu \mathrm{mol}$ norleucine and $2.5 \mu \mathrm{mol}$ carnosine in a volume of $50 \mu \mathrm{l}$, as internal standards. Deproteinization was completed within $30 \mathrm{~min}$ of collection. Deproteinized plasma and the remaining plasma were stored at $-10^{\circ}$ pending analysis. Plasma samples were analysed for glucose (Huggett \& Nixon, 1957) and urea (Chaney \& Marbach, 1962).

\section{Abomasal samples}

At the end of the Latin-Square experiment, measurements were made to estimate the flow of $\mathrm{N}$ into the abomasum resulting from the basal ration. The ration shown in Table $\mathrm{I}$, but containing ro $\mathrm{g}$ chromium sesquioxide $/ \mathrm{kg}$ in place of bone meal, was fed for $10 \mathrm{~d}(2 \cdot 5 \mathrm{~kg} / \mathrm{d})$. On the last $3 \mathrm{~d}$, abomasal contents were sampled by withdrawing $50 \mathrm{ml}$ every $8 \mathrm{~h}$. Samples were pooled for each animal, stored at $-10^{\circ}$ and freezedried. Diet and freeze-dried samples were analysed for chromium sesquioxide 
Table 3. Production of milk and milk constituents by goats given the basal ration $\dagger$ alone and with abomasal infusions of 15,30 and $45 \mathrm{~g}$ casein/d

\begin{tabular}{|c|c|c|c|c|c|c|}
\hline \multirow[b]{2}{*}{ Constituent } & \multicolumn{4}{|c|}{ Casein infused $(g / d)$} & \multirow[b]{2}{*}{ SE } & \multirow{2}{*}{$\underset{\text { linear }}{F}$} \\
\hline & ○ & 15 & 30 & 45 & & \\
\hline Milk (g/d) & $24 \circ 5$ & 2505 & 2798 & 2938 & $83 \cdot 0$ & $* *$ \\
\hline $\begin{array}{l}\text { Total solids } \\
\text { g/d } \\
\mathrm{g} / \mathrm{l}\end{array}$ & $\begin{array}{l}293 \cdot 9 \\
122 \cdot 4\end{array}$ & $\begin{array}{l}307 \cdot 3 \\
122 \cdot 7\end{array}$ & $\begin{array}{r}333.9 \\
\text { II9.4 }\end{array}$ & $\begin{array}{l}360.0 \\
122.7\end{array}$ & $\begin{array}{l}9.4 \mathrm{I} \\
1.50\end{array}$ & $\begin{array}{l}* * \\
\text { N.s. }\end{array}$ \\
\hline $\begin{array}{l}\text { Fat } \\
\text { g/d } \\
\mathrm{g} / \mathrm{l}\end{array}$ & $\begin{array}{r}96 \cdot 2 \\
40 \cdot 1\end{array}$ & $\begin{array}{r}103.0 \\
4 \mathrm{I} \cdot \mathrm{I}\end{array}$ & $\begin{array}{r}104.5 \\
37.4\end{array}$ & $\begin{array}{r}\text { I I3.3 } \\
38.8\end{array}$ & $\begin{array}{l}3.13 \\
0.80\end{array}$ & $\begin{array}{l}* * \\
\text { N.s. }\end{array}$ \\
\hline $\begin{array}{l}\text { Solids not fat } \\
\mathrm{g} / \mathrm{d} \\
\mathrm{g} / 1\end{array}$ & $\begin{array}{r}197 \cdot 8 \\
82 \cdot 3\end{array}$ & $\begin{array}{r}204 \cdot 3 \\
81 \cdot 6\end{array}$ & $\begin{array}{r}229 \cdot 4 \\
82 \cdot 1\end{array}$ & $\begin{array}{r}246 \cdot 6 \\
84 \cdot 0\end{array}$ & $\begin{array}{l}5.48 \\
0.90\end{array}$ & $\begin{array}{l}\text { **** } \\
\text { N.s. }\end{array}$ \\
\hline $\begin{array}{l}\text { Total protein } \\
\text { g/d } \\
\mathrm{g} / 1\end{array}$ & $\begin{array}{l}74 \cdot 3 \\
31^{\circ} \cdot 0\end{array}$ & $\begin{array}{l}76 \cdot 1 \\
30 \cdot 4\end{array}$ & $\begin{array}{l}86 \cdot 2 \\
30 \cdot 8\end{array}$ & $\begin{array}{l}91 \cdot 7 \\
31 \cdot 2\end{array}$ & $\begin{array}{l}\mathrm{I} 8 \mathrm{r} \\
0.60\end{array}$ & $\begin{array}{l}\text { **** } \\
\text { N.s. }\end{array}$ \\
\hline $\begin{array}{l}\text { Casein } \\
\mathrm{g} / \mathrm{d} \\
\mathrm{g} / \mathrm{l}\end{array}$ & $\begin{array}{l}59^{\circ} \mathrm{I} \\
24 \cdot 7\end{array}$ & $\begin{array}{l}60 \cdot 6 \\
24 \cdot 2\end{array}$ & $\begin{array}{l}68 \cdot 6 \\
24 \cdot 5\end{array}$ & $\begin{array}{l}73.4 \\
25.0\end{array}$ & $\begin{array}{l}1.55 \\
1.40\end{array}$ & $\begin{array}{l}\text { **** } \\
\text { N.s. }\end{array}$ \\
\hline $\begin{array}{l}\text { Lactose } \\
\text { g/d } \\
\mathrm{g} / \mathrm{l}\end{array}$ & $\begin{array}{r}\text { I I } 8.6 \\
49.3\end{array}$ & $\begin{array}{r}12 \mathrm{I} \cdot 2 \\
48.5\end{array}$ & $\begin{array}{r}136.0 \\
48.7\end{array}$ & $\begin{array}{r}\mathrm{I} 44 . \mathrm{I} \\
48.9\end{array}$ & $\begin{array}{l}5.12 \\
0.40\end{array}$ & $\begin{array}{l}* * * \\
\text { N.s. }\end{array}$ \\
\hline
\end{tabular}

(Czarnocki, Sibbald \& Evans, I960) and N. Abomasal samples and the casein infusate were hydrolysed with $6 \mathrm{M}-\mathrm{HCl}$ (Spitz, I973) in preparation for amino acid analysis. Dry matter (DM), total $\mathrm{N}$ and amino acid- $\mathrm{N}$ reaching the abomasum were calculated, assuming total recovery of chromium sesquioxide at the abomasum.

\section{Amino acid analysis}

Hydrolysates and deproteinized plasma samples were analysed for individual amino acids by ion-exchange chromatography on a Technicon TSM amino acid AutoAnalyzer (Technicon Instruments Corporation, Tarry Town, New York, USA). The estimates of tryptophan were unsatisfactory since it was recorded as a very broad peak which was difficult to measure accurately. Values of tryptophan have, therefore, not been included in the results. The more appropriate terms (Harper, 1974) 'indispensable' and 'dispensable' have been used throughout this paper in place of the conventional terms 'essential' and 'non-essential' respectively. Amino acids were separated into the two categories on the basis of in vitro studies carried out by Schingoethe, Hagemann \& Larson (1967).

\section{Statistical analysis}

Data were analysed according to conventional Latin-Square analysis procedures and are presented as treatment means. Treatment effects were partitioned to test for linearity. 
Table 4. Dry matter (DM) and nitrogen balance results for goats given basal ration $\dagger$ alone and with abomasal infusions of 15,30 and $45 g$ casein/d

\begin{tabular}{|c|c|c|c|c|c|c|}
\hline & & Casein & used $(g / d$ & & & \\
\hline & 0 & 15 & 30 & 45 & $\mathrm{SE}$ & linear \\
\hline DM intake $(\mathrm{g} / \mathrm{d})$ & 2178 & 2186 & 2175 & 2167 & $13 \cdot 19$ & N.s. \\
\hline DM digestibility & 0.67 & 0.67 & 0.67 & 0.66 & 0.009 & N.s. \\
\hline $\begin{array}{l}N \text { input }(g / d) \\
\text { Basal ration } \\
\text { Infusate } \\
\text { Total }\end{array}$ & $\begin{array}{r}44 \cdot 5^{8} \\
0.00 \\
44 \cdot 5^{8}\end{array}$ & $\begin{array}{r}43 \cdot 23 \\
2 \cdot 09 \\
45 \cdot 32\end{array}$ & $\begin{array}{r}43 \cdot 99 \\
4 \cdot 19 \\
48 \cdot 18\end{array}$ & $\begin{array}{r}43 \cdot 57 \\
6 \cdot 28 \\
49 \cdot 85\end{array}$ & $\frac{0.341}{0.085}$ & $\frac{\text { N.s. }}{* * * *}$ \\
\hline $\begin{array}{l}\text { N output }(\mathrm{g} / \mathrm{d}) \\
\text { Faeces } \\
\text { Urine }\end{array}$ & $\begin{array}{l}14.83 \\
13.07\end{array}$ & $\begin{array}{l}14.60 \\
14.05\end{array}$ & $\begin{array}{r}14.24 \\
14.20\end{array}$ & $\begin{array}{l}14.71 \\
14.91\end{array}$ & $\begin{array}{l}0.331 \\
0.587\end{array}$ & $\begin{array}{l}\text { N.s. } \\
\text { N.s. }\end{array}$ \\
\hline $\begin{array}{l}\text { Total productive } N(g / d) \\
\text { Milk N }(g / d) \\
\text { Retained N }(g / d) \\
\text { Absorbed N (g/d) } \\
\text { N digestibility }\end{array}$ & $\begin{array}{r}16.67 \\
11 \cdot 31 \\
+5.37 \\
29 \cdot 74 \\
0.67\end{array}$ & $\begin{array}{r}r 6.68 \\
11 \cdot 61 \\
+5.06 \\
30.73 \\
0.68\end{array}$ & $\begin{array}{r}19.73 \\
13.16 \\
+6.58 \\
33.94 \\
0.71\end{array}$ & $\begin{array}{r}20.23 \\
14.36 \\
+5.87 \\
35.14 \\
0.71\end{array}$ & $\begin{array}{l}0.691 \\
0.340 \\
0.471 \\
0.529 \\
0.009\end{array}$ & $\begin{array}{l}* * \\
* * * \\
\text { N.s. } \\
* * * \\
\text { N.S. }\end{array}$ \\
\hline
\end{tabular}

RESULTS

Two goats left about $300 \mathrm{~g}$ food/d during the period of infusion of $15 \mathrm{~g}$ casein/d. These periods were repeated when the goats had returned to normal food intake. Apart from this incident, the experiment proceeded according to plan and the animals remained healthy throughout.

\section{Milk production}

Treatment effects on the production of milk and milk constituents can be seen from Table 3. As the level of infused protein increased, there was a linear increase in the production of milk and all milk constituents. Treatment effects on milk composition were not significant.

\section{$N$ balance}

It may be seen from Table 4 that the basal intakes of DM and $\mathrm{N}$ were similar on all four treatments, while the total $\mathrm{N}$ inputs were progressively increased by the infusions. All the infused $\mathrm{N}$ appeared to be absorbed since there was no increase in the $\mathrm{N}$ content of the faeces as the infusions of casein increased. The output of $\mathrm{N}$ in urine increased slightly but not significantly $(P>0.05)$ with increasing amount of casein infused. There was a linear increase in $\mathrm{N}$ absorbed and total productive $\mathrm{N}$, the main increment of which appeared in milk. The goats were in positive $\mathrm{N}$ balance on the basal ration and the quantity of $\mathrm{N}$ retained was not affected by the treatments.

Arterial plasma concentrations, mammary extractions (calculated as the difference between arterial and caudal superficial epigastric vein plasma) and percentage extractions for plasma glucose and urea are given in Table 5. The concentration of glucose in arterial plasma was not significantly affected by treatments but there was a linear increase in the percentage extraction of glucose by the mammary gland. Neither 
Table 5. Plasma concentrations in the carotid artery $(C)$, mammary gland extraction $(U)$ and the percentage extraction $(U / C \times 100)$ for glucose and urea $(m m o l / l)$ of goats given the basal ration $\uparrow$ alone and with abomasal infusions of $\mathrm{r}, 30$ and $45 \mathrm{~g}$ casein/d

\begin{tabular}{|c|c|c|c|c|c|c|}
\hline \multirow[b]{3}{*}{ Glucose } & \multicolumn{4}{|c|}{ Casein infused $(\mathrm{g} / \mathrm{d})$} & \multirow[b]{2}{*}{$\mathrm{SE}$} & \multirow{2}{*}{$\underset{\text { linear }}{F}$} \\
\hline & 0 & I 5 & 30 & 45 & & \\
\hline & & & & & & \\
\hline C & $3 \cdot 57$ & $3.5 I$ & $3 \cdot 60$ & 3.05 & 0.13 & N.S. \\
\hline $\mathrm{U}$ & 1.02 & $1 \cdot 12$ & $I \cdot 31$ & $I \cdot 25$ & 0.08 & N.s. \\
\hline $\mathrm{U} / \mathrm{C} \times 100$ & $28 \cdot 5$ & $31 \cdot 8$ & $36 \cdot 4$ & $4 I \cdot 1$ & $2 \cdot 5$ & $*$ \\
\hline Urea & & & & & & \\
\hline C & 3.58 & 4.07 & 3.55 & $4: 39$ & $0.54 \mathrm{r}$ & N.S. \\
\hline $\mathrm{U}$ & -0.084 & -0.133 & -0.197 & 0.067 & $0.68 \mathrm{r}$ & N.s. \\
\hline $\mathrm{U} / \mathrm{C} \times 100$ & $-2 \cdot 4$ & $-3 \cdot 3$ & $-5 \cdot 6$ & $1 \cdot 5$ & 2.6 & N.S. \\
\hline
\end{tabular}

the arterial plasma concentrations nor mammary extractions of urea were affected by the treatments.

Table 6 shows the amino acid concentrations in arterial plasma and their extraction by the mammary gland. There were linear increases in concentrations of total indispensable amino acids and the ratio, indispensable: dispensable amino acids in arterial plasma associated with the infusions. Although there was a trend towards the mammary uptake of indispensable amino acids being linear, this was not statistically significant $(P>0.05)$.

Individual amino acid data show that there was a linear increase in arterial plasma concentrations of threonine, valine, leucine, lysine and histidine. Also, there was a linear increase in mammary extractions of threonine and lysine.

Of the dispensable amino acids, there was a linear increase in the arterial plasma concentrations of cystine and a linear decrease in the concentration of glutamic acid + glutamine. Mammary extractions of dispensable amino acids were not significantly affected by treatments.

\section{Amino acid supply from the basal diet and infusions}

The proportions of DM and $N$ digested in the stomach were $0.3^{8} \pm 0.03$ (SE) and $0.26 \pm 0.07$ respectively, so that $1425 \pm 73 \mathrm{~g} \mathrm{DM}$ and $32.5 \pm 3 . \mathrm{g} \mathrm{N}$ flowed daily from the abomasum in animals on the basal diet. The quantities of individual amino acids flowing to the duodenum per $\mathrm{d}$ on the basal ration and during the infusions can be seen from Table 7 .

Estimates of digesta flow using chromium sesquioxide as a marker may be subject to error for reasons discussed by Faichney (1972). However, the quantity of $\mathrm{N}$ absorbed from the reticulorumen $(\mathrm{I} 2 \cdot \mathrm{I} \mathrm{g} / \mathrm{d}$ ) was very similar to $\mathrm{N}$ output in urine ( $13 . \times \mathrm{g} / \mathrm{d}$ ), and the $\mathrm{N}$ absorbed post-ruminally $(17.6 \mathrm{~g} / \mathrm{d}$ ) was similar to the total productive $N(16.7 \mathrm{~g} / \mathrm{d})$. These findings are in agreement with the fact that the $N$ from the reticulorumen is absorbed as ammonia- $\mathrm{N}$ while that absorbed post-ruminally 
Table 6. Plasma concentrations in the carotid artery $(C)$ and extraction by the mammary gland $(U)$ of plasma free amino acids ( $\mu$ molll plasma) in goats given the basal ration $\dagger$ alone and with infusions of 15,30 and $45 \mathrm{~g}$ casein/d

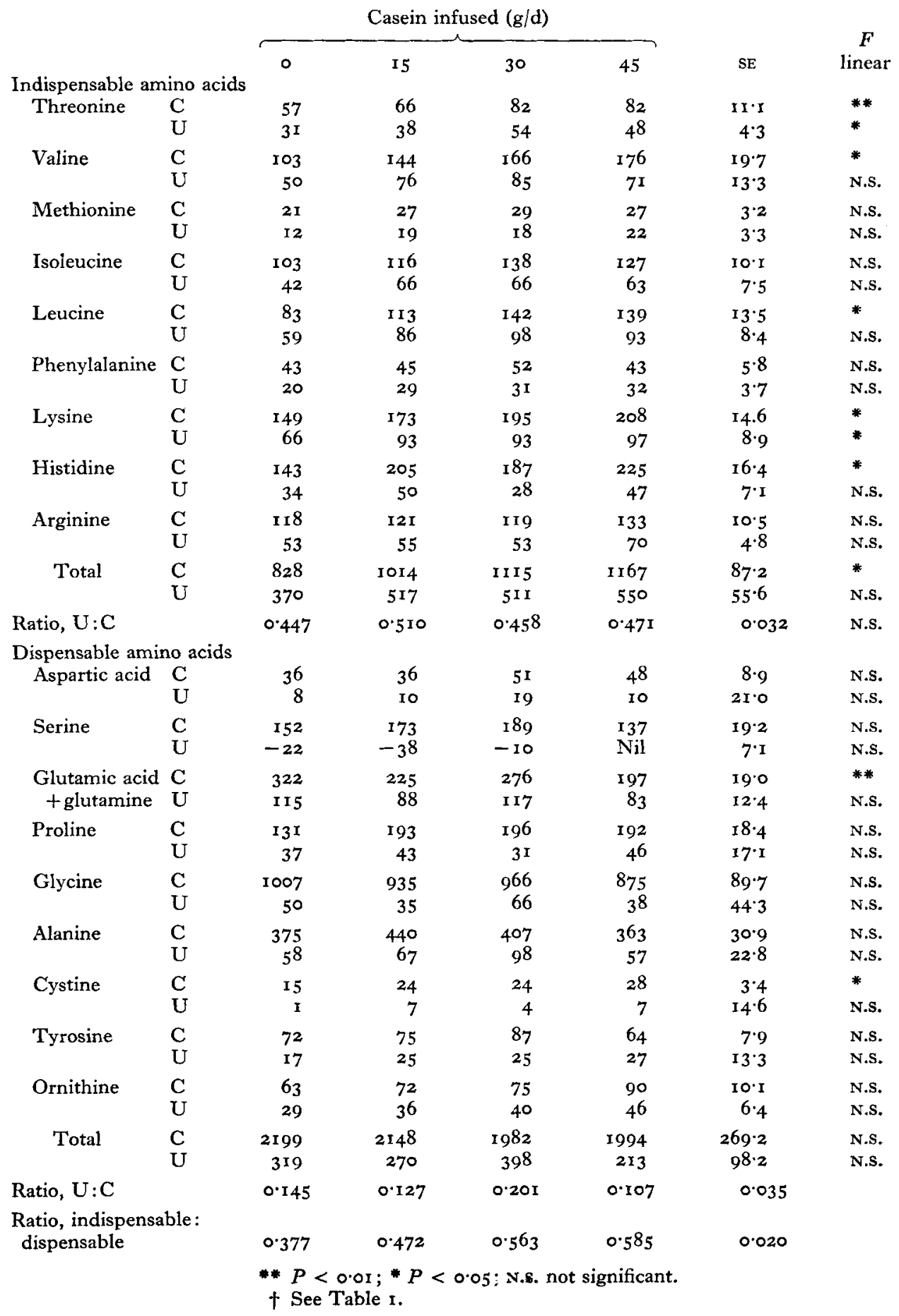


Table 7. Amino acids entering the abomasum (mmol/d) of goats given the basal ration $\dagger$ alone and with abomasal infusions of 15,30 and $45 \mathrm{~g}$ casein/d

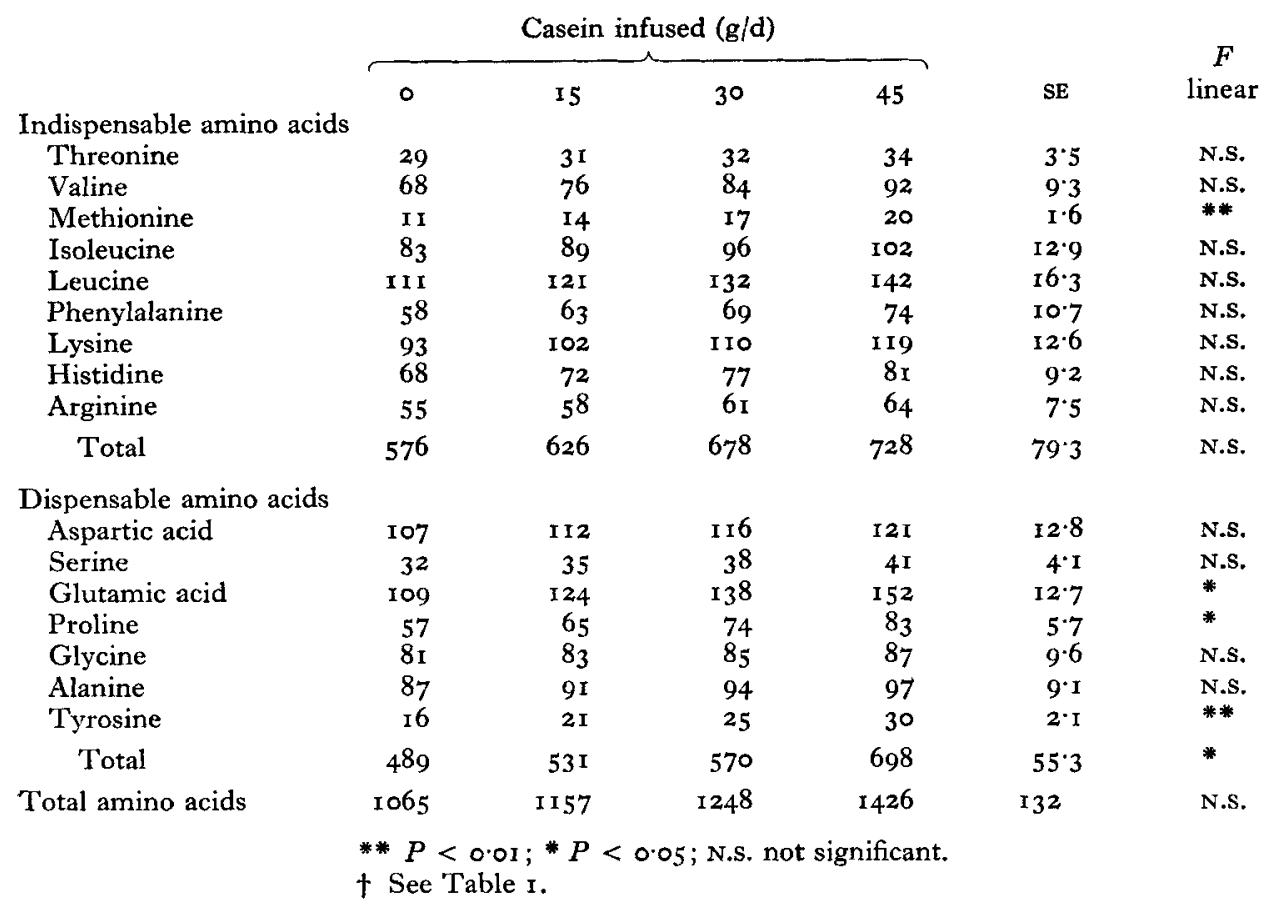

is mainly amino-N. Total amino acid- $\mathrm{N}$ flowing from the abomasum on the basal diet was $22.3^{6} \mathrm{~g} / \mathrm{d}$. If it is assumed that its digestibility was 0.74 (Clarke, Ellinger \& Phillipson, I 966), the amino acid-N absorbed from the basal diet becomes I6.4 $\mathrm{g} / \mathrm{d}$, which again is similar to the total productive $\mathrm{N}$ on the basal ration. It appears, therefore, that spot samples from the abomasum using chromium sesquioxide as a marker provided estimates of total $\mathrm{N}$ and amino- $\mathrm{N}$ flow consistent with measured $\mathrm{N}$ utilization in the animals.

\section{DISCUSSION}

Daily intakes of digestible DM and DCP from the basal diet were similar on all four treatments, so that treatment effects may be attributed to infusions of the casein solution. It was assumed that antibiotics included in this solution had a negligible effect on adult animals which were on a fixed level of intake. The present study is the first in which the lactating goat has been employed to evaluate the effects on milk production of postruminal supplementation with casein, previous studies being carried out with cows (Clark et al. 1973; Derrig et al. 1974; Vik-Mo et al. 1974a). In these cattle studies, infusions of casein at rates equivalent on a live weight basis to the highest used in the present study led to increases in milk production of about $10 \%$, which are substantially less than the $22 \%$ increase in yield recorded in the present experiment. A feature of the cattle studies was the relatively high crude protein 
content of the basal ration fed to cows. Although these were considerably higher than the 1 I $0 \mathrm{~g}$ crude protein $/ \mathrm{kg}$ ration which we fed, the goats were in substantial positive $\mathrm{N}$ balance on the basal ration.

Duncan (1966) critically examined the $\mathrm{N}$ balance trial in nutrition studies, and pointed out that there was a tendency to over-estimate $\mathrm{N}$ retained. Losses of $\mathrm{N}$ in hair and scurf were not estimated in the present study, but if the value for cattle (Agricultural Research Council, I965) is used, the loss would be about $0.3-0.5 \mathrm{~g} \mathrm{~N} / \mathrm{d}$. This still leaves a positive gain of about $5 \mathrm{~g} \mathrm{~N} / \mathrm{d}$ which is in excess of $10 \%$ of the daily intake. A small proportion of faecal $\mathrm{N}$ may have been lost during drying but the occurrence of such a large error in either experimental or analytical techniques does not seem likely, so it is reasonable to conclude that the animals were indeed in positive $\mathrm{N}$ balance. This suggests that milk production in goats on the basal ration was not limited by a simple deficiency of dietary protein, and that production responses to infused casein were attributable to specific properties of the casein. In the present study, the increase in the production of milk protein when casein was infused was similar to that of milk. This is in contrast to the findings in cows (Broderick, Kowalczyk \& Satter, 1970; Clarke et al. 1973; Spires, Clark \& Derrig, 1973; Derrig et al. 1974; Vik-Mo et al. 1974a) of a specific effect on milk protein production.

Concentrations of urea in plasma were low and unaffected by treatments, in contrast to the report of Vik-Mo, Huber, Bergen \& Lichtenwalner ( $1974 b$ ) that plasma urea concentrations increased following infusions of casein. This apparent discrepancy may be due to differences in the $\mathrm{N}$ intake from the basal ration.

The results of the present study are in conformity with previous reports that postruminal infusion of casein leads to increased concentrations of free amino acids in the blood (Hogan, Weston \& Lindsay, I968; Broderick, Satter \& Harper, r974; Derrig et al. 1974; Vik-Mo et al. $1974 b$ ). The specific increase in indispensable amino acids leading to a higher ratio, indispensable: dispensable amino acids is also consistent with these earlier studies. Data for individual amino acids, however, tend to vary between experiments and their significance is difficult to interpret.

The accuracy of all measurements of plasma constituents and mammary extractions are limited by the errors inherent in these procedures (Barry, I96I). The most serious source of error in the present experiment would appear to be that due to diurnal variations in plasma metabolites, since only one pair of samples was taken from each animal in each period. Recently, Mepham \& Linzell (1974) measured hour to hour differences across the mammary glands of the goat and concluded that the variation was homogeneous for all indispensable amino acids and heterogeneous for some of the dispensable amino acids (aspartic acid, glycine and alanine). Hume, Jacobson \& Mitchell (1972) showed that concentrations of amino acids in portal vein plasma showed a diurnal variation when sheep were fed once daily, but that no such pattern occurred when they were fed every $2 \mathrm{~h}$. In the present study, efforts were made to minimize these variations by feeding and infusing continuously and by bleeding at the same time of day each time. Multiparous goats were selected for the experiment and the external pudic veins were clamped manually during the sampling as recommended by Linzell (1960) in order to obtain a venous blood sample representative of blood 
Table 8. Output of indispensable amino acids in milk (\% that absorbed from the gut) in goats given the basal ration* alone and with abomasal infusions of 15,30 and $45 g$ casein/d

\begin{tabular}{lrrrr} 
& \multicolumn{4}{c}{ Casein infused $(\mathrm{g} / \mathrm{d})$} \\
\cline { 2 - 5 } & 0 & 15 & 30 & 45 \\
Threonine & 81 & 77 & 81 & 83 \\
Valine & 77 & 69 & 69 & 68 \\
Methionine & 164 & 129 & 118 & 108 \\
Isoleucine & 46 & 43 & 45 & 46 \\
Leucine & 83 & 75 & 76 & 75 \\
Phenylalanine & 89 & 77 & 76 & 73 \\
Lysine & 68 & 62 & 64 & 63 \\
Histidine & 40 & 38 & 40 & 40 \\
Arginine & 39 & 37 & 39 & $4 \mathrm{I}$ \\
& $*$ See Table I.
\end{tabular}

draining the mammary parenchyma. In view of the precautions taken, it would seem that the data are realistic.

Clark (1975) reviewed results of lactational responses to postruminal casein infusions which led to an increase in milk production. He suggested that the responses could be due to one or a combination of the following.

1. Infusion of casein increases the supply to the animal of one or more specific amino acids that are deficient in the digesta passing from the rumen.

2. Casein infusions increase the supply of glucogenic amino acids to the liver and, therefore, increase the availability of glucose to the mammary gland.

3. Casein infusions, directly or indirectly, effect the release of hormones likely to stimulate milk production.

In relation to the first suggestion, we have attempted to construct amino acid balances (Table 8) in which the output of individual indispensable amino acids in milk is expressed as a percentage of their apparent absorption from the intestine. The absorption of amino acids was calculated by applying the digestibility factors reported for medium-cut pelleted grass by Coelho Da Silva, Seeley, Beever, Prescott \& Armstrong (1972) to the amino acids entering the abomasum from the basal diet (Table 6), and assuming that the amino acids from the infused casein were completely absorbed. Outputs of amino acids in milk were based on analysis of goat milk carried out in this laboratory (S. S. E. Ranawana, R. C. Kellaway \& P. J. McMahon, unpublished results). It can be seen (Table 8) that in animals on the basal ration, the availability of methionine was considerably less than its output in milk. In our experience, however, the estimation of methionine is subject to an error of $\pm 12 \cdot 1 \%$, and although this could easily account for the small discrepancies seen when casein was infused, the difference on the basal ration would appear too large to be explained in this manner. It is possible that the goats drew on body reserves to meet the deficit, since this has been shown to take place in cows (Moe, Tyrell \& Flatt, 1971; Paquay, de Baere \& Lousse, 1972). Such a mobilization of body tissue, however, is inconsistent with the finding that the goats were in positive $\mathrm{N}$ balance on the basal ration. The 
other amino acids that may have been in short supply are phenylalanine, leucine and threonine, while the supply of arginine, histidine and isoleucine appear to be in excess of requirements. These results are in contrast to those of Bigwood (I964), who concluded from his studies that lysine was likely to be the first limiting amino acid. It must be pointed out, however, that these measurements were based on a number of assumptions. Although, as discussed earlier, the results from the present study are also subject to considerable error, it seems possible that the milk yield response to casein infusion may have been due to an increased supply of critical amino acids, especially methionine.

The second suggestion of Clark (1975) has been investigated, by infusing similar quantities of casein and glucose post-ruminally in cows. In one experiment, milk production was increased by both casein and glucose (Vik-Mo et al. 1974a) while in others (Clark et al. 1973; Tyrell, Bolt, Moe \& Swan, 1972) milk yield was increased only by casein. In an experiment recently concluded in this laboratory (S. S. E. Ranawana, R. C. Kellaway, E. F. Annison \& G. Bennett, unpublished results), infusions of glucose postruminally into goats increased glucose entry rate but did not stimulate milk yield, while infusion of similar amounts of casein increased milk production. Infusion of glucose either intravenously (Linzell, 1967) or intra-arterially (Mepham \& Linzell, 1974) increased milk production. Although it is not possible to draw firm conclusions, it seems likely that when glucose infusions do cause increases in milk production, they do so by a mechanism different from that by which casein infusions stimulate milk yield.

The third suggestion of Clark (1975), that the responses to casein infusion may be the result of release of hormones which stimulate milk production, is attractive. There is convincing evidence that administration of growth hormone to lactating cows increases both milk yield and the efficiency of food utilization (Cowie, 1966; Machlin, 1973). Moreover, it has been demonstrated that the levels of growth hormone in plasma of cows are elevated following intravenous infusions of arginine or casein hydrolysate (Hertelendy, Machlin \& Kipnis, 1970; Hertelendy, Takahashi, Machlin \& Kipnis, 1970). Recently, Hart, Bines, Balch \& Cowie (1975) reported that, when compared to beef cows which tended to increase body tissue rather than produce milk, lactating cows had higher circulating levels of growth hormone and lower levels of insulin and prolactin.

Clearly a satisfactory explanation of the responses observed in the present study awaits a fuller understanding of the mechanisms by which available nutrients are utilized by the lactating ruminant. The lactating goat should serve as an excellent model for further studies.

We thank Miss K. Maurer and Mr R. Moore for technical assistance. The study was supported by the Australian Dairying Research Committee. 


\section{REFERENCES}

Agricultural Research Council (1965). Nutrient Requirements of Farm Animals. No. 2. Ruminants, p. I56. London: Agricultural Research Council.

Barry, J. M. (1961). In Milk: The Mammary Gland and its Secretion, vol. I, p. 389 [S. K. Kon and A. T. Cowie, editors]. New York: Academic Press.

Bigwood, E. J. (1964). In The Role of the Gastrointestinal Tract in Protein Metabolism, p. 155 [H. N. Munro, editor]. Oxford: Blackwell Scientific Publications.

Broderick, G. A., Kowalczyk, T. \& Satter, L. D. (1970). F. Dairy Sci. 53, I7r4.

Broderick, G. A., Satter, L. D. \& Harper, A. E. (1974). F. Dairy Sci. 57, ror 5.

Broster, W. H. (1972). In Handbuch du Tierernahrüng, vol. 2, p. 292 [W. Lenkeit, K. Breirem and E. Crasemann, editors]. Hamburg and Berlin: Paul Parey.

Chaney, A. L. \& Marbach, E. P. (1962). Clin. Chem. 8, гзо.

Clark, J. H. (1975). Ұ. Dairy Sci. 58, 1179.

Clark, J. H., Spires, H. R. \& Derrig, R. G. (1973). F. Anim. Sci. 37, 340.

Clarke, E. M. W., Ellinger, G. \& Phillipson, A. T. (1966). Proc. R. Soc. B 166, 63.

Coelho Da Silva, J. F., Seeley, R. C., Beever, D. E., Prescott, J. H. D. \& Armstrong, D. G. (r972). Br. F. Nutr. 28, 357.

Cowie, A. T. (1966). In The Pituitary Gland, vol. II, p. 412 [G. W. Harris and B. T. Donovan, editors]. London: Butterworths.

Cowie, A. T., Hartmann, P. E. \& Turvey, A. (r 969). F. Endocr. 43, 651.

Czarnocki, J., Sibbald, I. R. \& Evans, E. V. (1960). Can. F. Anim. Sci. 4r, r67.

Davis, J. G. (1959). Milk Testing, and ed., p. 99. London: Dairy Industries.

Davis, J. G. \& McDonald, F. J. (1953). Richmond's Dairy Chemistry, 5th ed., p. 358. London : Charles Griffin \& Co. Ltd.

Derrig, R. G., Clark, J. H. \& Davis, C. L. (1974). F. Nutr. 104, 55 I.

Driedger, A., Condon, R. J., Nimrick, K. O. \& Hatfield, E. E. (1970). F. Anim. Sci. 31, 772.

Duncan, D. L. (1966). In Recent Advances in Animal Nutrition, p. 5 I [J. R. Abrams, editor]. London: J. \& A. Churchill.

Faichney, G. J. (1972). F. agric. Sci., Camb. 79, 493.

Hale, G. D., Jacobson, D. R. \& Hemken, R. W. (1972). F. Dairy Sci. 55, 689.

Harper, A. E. (1974). F. Nutr. r04, 965.

Hart, I. C., Bines, J. A., Balch, C. C. \& Cowie, A. T. (1975). Life Sciences 16, I285.

Hertelendy, F., Machlin, L. \& Kipnis, D. M. (1970). Endocrinology 84, 192.

Hertelendy, F., Takahashi, K., Machlin, L. J. \& Kipnis, D. M. (1970). Gen. comp. Endocr. 14, 72.

Hogan, J. P., Weston, R. H. \& Lindsay, J. R. (1968). Aust. F. biol. Sci. 21, 263.

Hugget, A. St G. \& Nixon, D. A. (1957). Biochem. F. 66, 12 P.

Hume, I. D., Jacobson, D. R. \& Mitchell, G. E. Jr (I972). F. Nutr. 102, 495.

Kellaway, R. C., Ranawana, S. S. E., Buchanan, G. H. \& Smart, L. (1974). F. Dairy Res. 41, 305.

Linzell, J. L. (1960). F. Physiol., Lond. I53, 481.

Linzell, J. L. (1967). F. Physiol., Lond. 190, 347.

Linzell, J. L. \& Mepham, T. B. (I974). F. Dairy Res. 4x, Iог.

Machlin, L. J. (1973). F. Dairy Sci. 56, 575.

McKenzie, H. A. \& Wallace, H. S. (1954). Aust. F. Chem. 7, 55.

Mepham, T. B. \& Linzell, J. L. (1974). F. Dairy Sci, 41, 95.

Moe, D. W., Tyrell, H. F. \& Flatt, W. P. (1971). F. Dairy Sci. 54, $54^{8}$.

Paquay, R., de Baere, R. \& Lousse, A. (1972). Br. F. Nutr. 27, 27.

Perry, J. L. \& Hansen, S. (1969). Clinica chim. Acta 25, 53 .

Rowland, S. J. (1938). F. Dairy Res. 9, 42.

Satter, L. D. \& Roffler, R. E. (I975). F. Dairy Sci. 58, I219.

Schingoethe, D. J., Hagemann, E. C. \& Larson, B. L. (1967). Biochim. biophys. Acta 148, 469.

Spires, H. R., Clark, J. H. \& Derrig, R. G. (r973). F. Dairy Sci. 56, 664.

Spitz, H. D. (1973). Analyt. Biochem. 56, 66.

Tyrell, H. F., Bolt, D. V., Moe, P. W. \& Swan, H. (1972). F. Anim. Sci. 35, 277.

Vik-Mo, L., Emery, R. S. \& Huber, J. T. (1974a). F. Dairy Sci. 57, 869.

Vik-Mo, L., Huber, J. T., Bergen, W. G. \& Lichtenwalner, R. E. (1974b). F. Dairy Sci. 57, 1024. 